\title{
Histopathological and biochemical effects of green tea and/or licorice aqueous extracts on thyroid functions in male albino rats intoxicated with dimethylnitrosamine
} A Abd El Mgeed ${ }^{* 1}$, M Bstawi $^{1}$, U Mohamed ${ }^{2}$ and M Abdel Gabbar ${ }^{1}$

Address: ${ }^{1}$ Faculty of Science, Biochemistry Subdivision, Beni Sweif Branch, Cairo University, Cairo, Egypt and ${ }^{2}$ Department of Physiology, Beni Sweif Branch, Cairo University, Cairo, Egypt

Email: A Abd El Mgeed* - ahmgedoeg@yahoo.com; M Bstawi - ahmgedoeg@yahoo.com; U Mohamed - ahmgedoeg@yahoo.com; M Abdel Gabbar - ahmgedoeg@yahoo.com

* Corresponding author

Published: 12 January 2009

Nutrition \& Metabolism 2009, 6:2 doi:10.1186/1743-7075-6-2
Received: 20 March 2007

Accepted: 12 January 2009

This article is available from: http://www.nutritionandmetabolism.com/content/6/1/2

(c) 2009 El Mgeed et al; licensee BioMed Central Ltd.

This is an Open Access article distributed under the terms of the Creative Commons Attribution License (http://creativecommons.org/licenses/by/2.0), which permits unrestricted use, distribution, and reproduction in any medium, provided the original work is properly cited.

\begin{abstract}
Objective: To investigate histopathological and biochemical effects of green tea and/or licorice aqueous extracts in thyroid functions in male albino rats intoxicated with Dimethylnitrosamine.

Methods: 40 Male albino rats were divided into two main groups, 20 normal rats and 20 DMN intoxicated rats. Normal rats were subgrouped into 4 equal groups, group $A$ without treatment (controls), group $B$ treated with green tea, group $C$ treated with licorice, group $D$ treated with green tea and licorice. DMN intoxicated rats were subgrouped into 4 equal groups, group $E$ treated with DMN, group $F$ treated with DMN and green tea, group $G$ treated with DMN and licorice, group $\mathrm{H}$ treated with $\mathrm{DMN}$, green tea and licorice. The rats were permitted for free access to solubilized extracts of green tea and or licorice for 4 weeks. All rats in groups E, F, G, H were treated by intraperitoneal DMN (4 mg dissolved in $2.5 \mathrm{ml}$ distilled water/kg body weight) seven times every 2 days in the first two weeks. Plasma total triiodothyronine and tetraiodothyronine were determined by radioimmunoassay. Thyroxine 5-monodeiodinase activity of liver was determined by spectrophotometeric method. Plasma thyroid stimulating hormone was determined by chemiluminometric technique. Histopathological examination was conducted.
\end{abstract}

Results: Histopathologically thyroid gland of DMN intoxicated rats showed degeneration (DG)and desquamation (DS) of the lining epithelium and atrophy of many acini with hyperemia $(H)$ in the stromal capillaries and In comparison with control, the administration of DMN alone induced decrease in plasma levels of T3 and T4 while it induced increase in plasma levels of TSH and hepatic activity of Thyroxine 5-monodeiodinase. Coadminstration of DMN and green tea attenuated the lowering effect of DMN on plasma levels of T3 and T4 and induced increase in these levels but values are still below normal ones while Co administration of DMN with licorice or mixture did not affect these levels. Co administration of green tea and/or licorice with DMN attenuated the rising effect of DMN on hepatic activity of Thyroxine 5--DI while augmented the rising effect of DMN on plasma level of TSH.

Conclusion: Aqueous extract of green tea may be effective in amelioration of biochemical effects and histopathological lesions induced by DMN. 


\section{Introduction}

Green tea the water extract of the dry leaves of the plant camellia sinensis, an evergreen shrub of the theaceae family, is a popular beverage commonly known as tea. A drink contains many compounds, including a mixture of polyphenols. Tea has been consumed by some human populations for many generations and, in some parts of the world, has been considered to have health - promoting potentials [1].

Glycyrrhiza glabra (Licorice) originated in the Mediterranean and Middle East has been used medically since at least 500 BC Ody [2]. It has been cultivated in Europe since at least the $16^{\text {th }}$ Century. It is sometimes known as the grand father of herbs [3].

Although a considerable body of information provides evidence supporting the preventive potential of green tea and licorice against diseases, proper understanding of the mechanisms by which tea and licorice reduce the risk of diseases is necessary.

As accumulative data were done by many previous authors $[4,5]$ on the active ingredients of green tea and licorice. The recent work was performed to evaluate histopathological and biochemical effects of green tea and/or licorice aqueous extracts on thyroid functions in male albino rats intoxicated with Dimethylnitrosamine.

\section{Methods}

Male albino rats weighing $150 \mathrm{~g} \pm 20$ were obtained from the animal house of Postgraduate and Research Institute, Alexandria University. The animals were kept in cages in environment with controlled temperature, humidity and illumination $\left(24-25^{\circ} \mathrm{C}, 50-60 \%\right.$ relative humidity, $12 \mathrm{~h}$ light/dark cycle). Animals were put on basal diet and water supply ad libitum. 40 Male albino rats were divided into two main groups, 20 normal rats and $20 \mathrm{DMN}$ intoxicated rats, normal rats were sub grouped into 4 equal groups, group A without treatment (controls), group B treated with green tea, group $\mathrm{C}$ treated with licorice, group $\mathrm{D}$ treated with green tea and licorice, DMN intoxicated rats were sub grouped into 4 equal groups, group E treated with DMN, group F treated with DMN and green tea, group $\mathrm{G}$ treated with DMN and licorice, group $\mathrm{H}$ treated with DMN, green tea and licorice. The animals were permitted for free access to solubilized extracts of green tea and or licorice for 4 weeks. All rats in groups E, F, G, H were given intra peritoneal DMN (4 mg dissolved in 2.5 $\mathrm{ml}$ distilled water/kg body weight) seven times every 2 days in the first two weeks. DMN doses injected to the animals were calculated according to Asakura et al., [6]. Chinese Green Tea was purchased from local market. Fresh tea was prepared by boiling $2.5 \mathrm{~g}$ of tea in $100 \mathrm{ml}$ of boiling distilled water for extraction and the extract was administrated ad-libitum to animals of group $\mathrm{B}$ and group F $(2.5 \% \mathrm{w} / \mathrm{v})$ according to $\mathrm{Bu}$ - Abbas et al., [7] for 4 weeks. Licorice was purchased from local market. Fresh licorice was prepared by boiling $2.5 \mathrm{~g}$ in $100 \mathrm{ml}$ of boiling distilled water for extraction and the extract was administrated ad-libitum to animals of group $C$ and group $G$ $(2.5 \% \mathrm{w} / \mathrm{v})$. Mixture of green tea and licorice was prepared by boiling $2.5 \mathrm{~g}$ of licorice and $2.5 \mathrm{~g}$ of tea in $100 \mathrm{ml}$ of boiling distilled water for extraction and the extract was administrated ad - libitum to rats of group D and group $\mathrm{H}(2.5 \% \mathrm{w} / \mathrm{v})$ for 4 weeks. After termination of the treatments the tested rats were sacrificed under diethyl ether anesthesia. Blood samples were collected from jugular vein in a little amount of 15\% EDTA solution then centrifuged at 3000 r.p.m for 15 minutes where the clear non haemolyzed supernatant plasma was quickly removed and kept at $-20^{\circ} \mathrm{C}$. Plasma levels of total $\mathrm{T}_{3}$ and $\mathrm{T}_{4}$ were determined by radioimmunoassay technique using CoatA-count total $\mathrm{T}_{3}$ and $\mathrm{T}_{4}$ kits purchased from Diagnostic Products Corporation (DPC), Los Angeles. Plasma thyroid stimulating hormone level was determined by chemiluminometric technique using ACS:180 Automated Chemiluminescence's System. Liver tissues were quickly excised, weighed and homogenized in $0.9 \%$ saline solution and kept at $-20^{\circ} \mathrm{C}$ for the assay of thyroxine $5^{-}-$ monodeiodinase (5- DI) [8] activity. For histopathological examination fixed specimens of thyroid gland were dehydrated in ascending ethanolic series, cleared in two changes of xylol and then impregnated and embedded in parablast at $60^{\circ} \mathrm{C}$. Sections of 4-5 $\mu \mathrm{m}$ in the thickness, were prepared using a rotary microtone, hydrated using a descending series of alcohol after dewaxication, and stained later with hematoxylin and eosin. The stained sections were examined by a Zeiss(M35W) microscope as described by Drury [9].

The data of the present study are presented as Mean \pm SD. The difference between groups was evaluated using ANOVA test and $\mathrm{p}<0.05$ was considered statistically significant.

\section{Results}

Effect of green tea (G), Licorice(L) or their mixture on \% of body weight increase, Liver weight/body weight and hepatic activity of thyroxine 5'-mondeiodenase (5'-DI), plasma levels of triiodothyronine $\left(\mathrm{T}_{3}\right)$, tetraiodothyronine $\left(\mathrm{T}_{4}\right)$, thyroid stimulating hormone (TSH) of normal and dimethylnitrosamine (D)-intoxicated male albino rats treated with green tea and/or licorice (L) are shown in Table (1) and Table (2), respectively.

The general effect of \% of body weight increase between groups was found to be very highly significant $(\mathrm{p}<0.001)$. Green tea, licorice or mixture of both, produced a significant decrease in the \% of body weight gain compared to 
Table I: Effects of green tea (G), licorice (L) or their mixture on $\%$ body weight increase and \% of liver weight/body weight of normal and dimethylnitrosamine (D)-intoxicated male albino rats.

\begin{tabular}{|c|c|c|c|c|}
\hline \multirow[t]{2}{*}{ Groups } & \multicolumn{2}{|c|}{ Increase of B.W. \% } & \multicolumn{2}{|c|}{ Liver weight./body weight. \% } \\
\hline & Mean \pm SE & $\%$ of change & Mean \pm SE & $\%$ of change \\
\hline Control & $7.9 \pm 0.228 c$ & & $2.7 \pm 0.267 c$ & \\
\hline $\mathrm{D}$ & $15.3 \pm 0.929 \mathrm{~b}$ & +93.67 & $3.1 \pm 0.218^{\mathrm{abc}}$ & $+|4.8|$ \\
\hline G & $2.0 \pm 0.045^{\mathrm{e}}$ & -74.48 & $2.9 \pm 0.066 \mathrm{bc}$ & +7.40 \\
\hline L & $1.7 \pm 0.058^{\mathrm{ef}}$ & -78.48 & $2.8 \pm 0.136 \mathrm{bc}$ & +3.70 \\
\hline$G+L$ & $2.6 \pm 0.04 I^{c}$ & -67.09 & $2.9 \pm 0.196 \mathrm{bc}$ & +7.4 \\
\hline$D+G$ & $0.6 \pm 0.17^{f}$ & -96.08 & $3.1 \pm 0.107^{a}$ & 0 \\
\hline$D+L$ & $27.8 \pm 0.924^{a}$ & +81.7 & $3.7 \pm 0.3 \mid 4^{a b}$ & 19.35 \\
\hline$D+G+L$ & $-4.1 \pm 0.17 I^{d}$ & -126.80 & $3.4 \pm 0.114^{\mathrm{ab}}$ & 9.68 \\
\hline
\end{tabular}

*Means that share the same superscript symbol are insignificantly different.

*\% of changes of groups D, G and $L$ are relative to control group. $* \%$ of changes of groups $D+G, D+L$ and $D+G+L$ are relative to $D$ group. normal control by $74.48 \%, 78.48 \%$ or $67.09 \%$, respectively (Table 1). The increase in the $\%$ of the body weight gain produced by DMN was $93.67 \%$ compared to control group. Licorice administration to DMN-treated rats produced more increase in body weight gain by $81.70 \%$ while green tea or the mixture of those extracts produced marked decrease compared to DMN-administered rats by $96.08 \%$ or $126.80 \%$. The general effect, in between groups, on \% of liver weight/body weight was found by one way ANOVA to be significant $(\mathrm{p}<0.05)$. Results indicated that green tea, licorice, DMN or the mixture exerted non significant change when compared to normal control group, (Table 1). The DMN groups administered with green tea, licorice or the mixture showed non significant changes compared to DMN control group, (Table 1). The general effect, in between groups, on the hepatic 5'-DI activity was found by one way ANOVA to be very highly significant $(\mathrm{p}<0.001)$. Licorice or DMN exerted significant elevation in thyroxine 5'-DI level compared to normal control group by $29.93 \%$ or $28.57 \%$, respectively (Table 2), while the mixture exerted significant decrease in that level by $34.69 \%$. On the other hand, green tea caused non significant decrease in its level. Green tea, licorice or the mixture decreased significantly 5'-DI level of DMNinjected rats by $37.04 \%, 23.81 \%$ or $58.73 \%$, respectively. The general effect, in between groups, on $\mathrm{T}_{3}$ level was found by one way ANOVA to be very highly significant ( $\mathrm{p}$ $<0.001)$. Data showed that DMN, licorice or the mixture produced a significant decrease in plasma level of $\mathrm{T}_{3}$ compared to normal control group by $76.91 \%, 23.00 \%$ or

Table 2: Effect of green tea (G), licorice (L) or their mixture on levels of plasma thyroid stimulating hormone (TSH), triiodothyronine $\left(T_{3}\right)$, and tetraiodothyronine $\left(T_{4}\right)$, Thyroxine 5 '-DI of normal and dimethylnitrosamine (D)-intoxicated male albino rats.

\begin{tabular}{|c|c|c|c|c|c|c|c|c|}
\hline \multirow[t]{2}{*}{ Groups } & \multicolumn{2}{|c|}{$\mathrm{TSH}(\mu \mathrm{lU} / \mathrm{ml})$} & \multicolumn{2}{|c|}{$\mathrm{T}_{4}(\mu \mathrm{g} / \mathrm{dl})$} & \multicolumn{2}{|c|}{$\mathrm{T}_{3}(\mathrm{ng} / \mathrm{dl})$} & \multicolumn{2}{|c|}{ Thyroxine 5'-DI (ng hr-1/mg protein) } \\
\hline & Mean \pm SE & $\begin{array}{c}\% \text { of } \\
\text { change }\end{array}$ & Mean \pm SE & $\begin{array}{c}\% \text { of } \\
\text { change }\end{array}$ & Mean \pm SE & $\begin{array}{c}\% \text { of } \\
\text { change }\end{array}$ & Mean \pm SE & $\begin{array}{c}\% \text { of } \\
\text { change }\end{array}$ \\
\hline Control & $0.09 \pm 0.009 g$ & & $31.7 \pm 1.10^{b}$ & & $792.7 \pm 22.0^{a}$ & & $\mathrm{I} .47 \pm 0.086^{b}$ & \\
\hline $\mathrm{D}$ & $0.21 \pm 0.003^{f}$ & +133.33 & $7.1 \pm 0.30^{c}$ & -77.60 & $183.0 \pm 5.70^{d}$ & -76.91 & $1.89 \pm 0.048^{a}$ & +28.57 \\
\hline G & $0.29 \pm 0.010^{c}$ & +222.22 & $34.1 \pm 0.69 a$ & +7.57 & $777.8 \pm 26.4^{a}$ & -1.88 & $\mathrm{I} .2 \mathrm{I} \pm 0.033^{\mathrm{bc}}$ & -17.69 \\
\hline L & $0.20 \pm 0.005^{f}$ & +122.22 & $32.1 \pm 0.74 b$ & +1.26 & $610.4 \pm 16.2^{b}$ & -23.00 & $1.91 \pm 0.105^{\mathrm{a}}$ & +29.93 \\
\hline$G+L$ & $1.35 \pm 0.002^{\mathrm{a}}$ & +1400 & $29.3 \pm 0.44 c$ & -7.57 & $581.1 \pm 18.1^{b}$ & -27.69 & $0.96 \pm 0.056^{d}$ & -34.69 \\
\hline$D+G$ & $0.25 \pm 0.007^{d}$ & +19.05 & $12.3 \pm 0.58^{d}$ & +73.24 & $234.2 \pm 8.7 c$ & +27.98 & $1.19 \pm 0.090 c$ & -37.04 \\
\hline$D+L$ & $0.85 \pm 0.016^{b}$ & +305.76 & $7.7 \pm 0.28 c$ & +8.45 & $195.7 \pm 7.5^{\mathrm{cd}}$ & +6.94 & $1.44 \pm 0.113^{b}$ & -23.81 \\
\hline$D+G+L$ & $0.23 \pm 0.012^{d c}$ & +9.52 & $8.2 \pm 0.5 \mathrm{Ic}^{\mathrm{c}}$ & 15.49 & $195.6 \pm 5.2^{\mathrm{cd}}$ & +6.89 & $0.78 \pm 0.036^{d}$ & -58.73 \\
\hline
\end{tabular}

*Means that share the same superscript symbol are insignificantly different.

*\% of changes of groups $D, G$ and $L$ are relative to control group.

$* \%$ of changes of groups $D+G, D+L$ and $D+G+L$ are relative to $D$ group. 
$27.69 \%$, respectively (Table 2), while green tea exerted non significant change in its level. Licorice or the mixture exerted no significant changes in the depleted $\mathrm{T}_{3}$ level of DMN-injected rats, although green tea produced a significant elevation in its level by $27.98 \%$. The general effect, in between groups, on $\mathrm{T}_{4}$ level was found by one way ANOVA to be highly significant $(\mathrm{p}<0.01)$ while green tea produced a significant elevation in its level compared to normal control group by $7.57 \%$ (Table 2). DMN or the mixture exerted a significant decrease in its level by $77.60 \%$ or $7.57 \%$ respectively. On the other hand, licorice exerted non significant change in its level. The treatment of DMN-injected animals with green tea induced a significant increase in that level by $73.24 \%$, while licorice or the mixture exerted non significant changes in its level. The general effect, in between groups, on TSH level was found by one way ANOVA to be very highly significant $(\mathrm{P}<$ 0.001 ). Green tea, licorice, DMN or the mixture caused a significant elevation in TSH level compared to normal control group by $222.22 \%, 122.22 \%, 133.33 \%$ or $1400.0 \%$, respectively (Table 2 ). Green tea, licorice or combination of both produced more increase of its elevated level of DMN-injected rats by $19.05 \%, 305.76 \%$ or $9.52 \%$, respectively.

Histopathological examination, Figure (1) demonstrates the normal thyroid tissue of a control rat. It is organized into follicles (F) filled with moderate amount of colloid (C)in their lumen and lined with cuboidal epithelial follicular cells (FC). The follicular acini are separated by follicular spaces or septa (S). Some parafollicular cells(PC) are present in between thyroid follicles. Figure (2) demonstrates the thyroid tissue of a rat intoxicated with DMN showing degeneration and desquamation (DS) of the lining epithelium and atrophy of many acini associated with hyperemia (h) in the stromal capillaries. Figure (3) demonstrates the thyroid tissue of a rat intoxicated with DMN

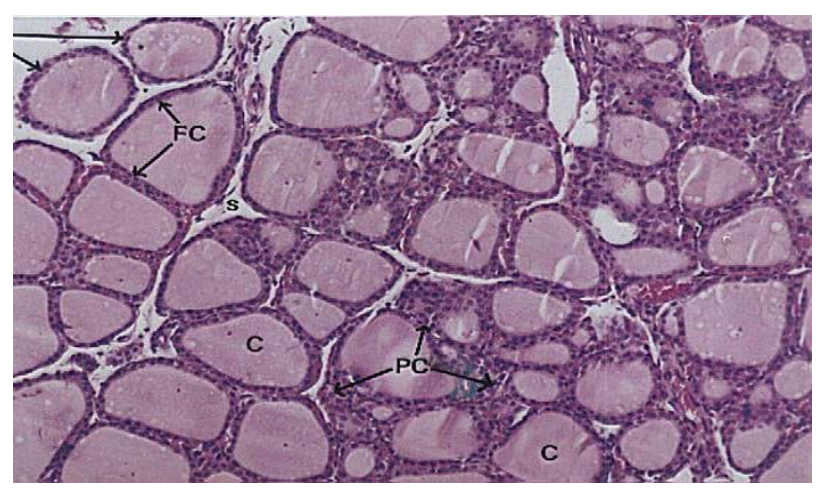

Figure I

Normal thyroid tissue of a control $\operatorname{rat}(\mathbf{H} \times \& E$ stain $\times 128$ ).

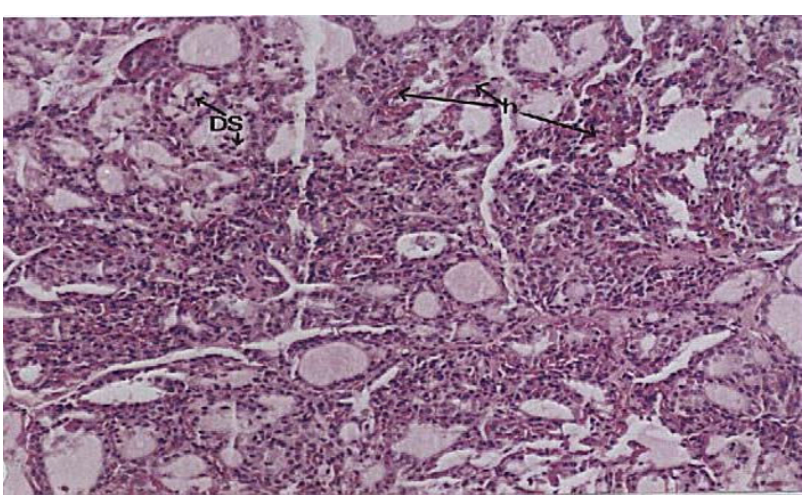

Figure 2

Thyroid tissue of a rat intoxicated with DMN $(\mathrm{H} \times \&$ E stain $\times$ (25).

and treated with a mixture of green tea and licorice showed marked amelioration of the lesions in thyroid tissue with enlargement of thyroid follicles. Figure (4) demonstrates the thyroid tissue of a rat intoxicated with DMN for 2 weeks and treated with green tea for 4 weeks showing focal hemorrhage (arrow) in the intracinar blood vessels. Figure (5) demonstrates The thyroid tissue of a rat intoxicated with DMN and treated with licorice showing great amelioration and normalization of thyroid tissue architecture.

\section{Discussion}

Body weight is frequently the most sensitive indicator of the adverse effects of xenobiotics, so it is considered as a determined parameter of toxicity testing. Administration of tested extracts decreased body weight gain in normal

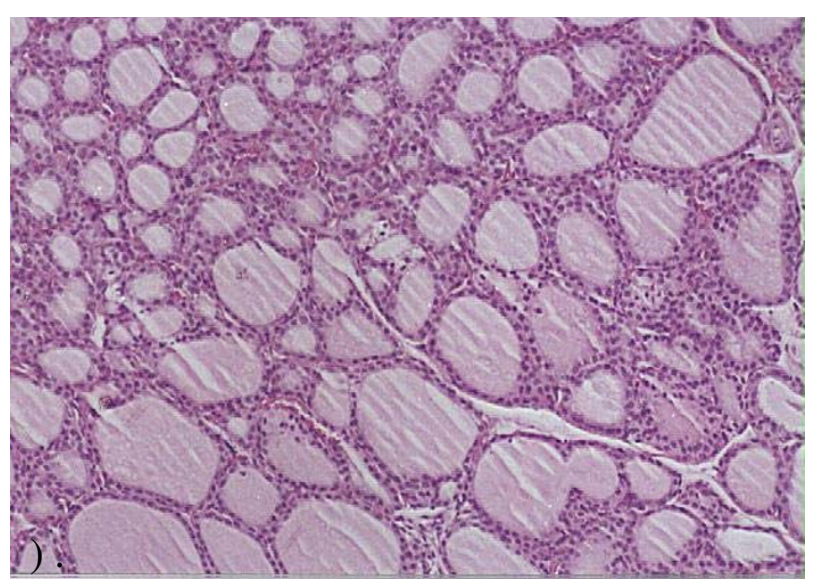

Figure 3

Thyroid tissue of a rat intoxicated with DMN treated with a mixture of green tea and licorice $(H \times \& E$ stain $\times(25)$. 


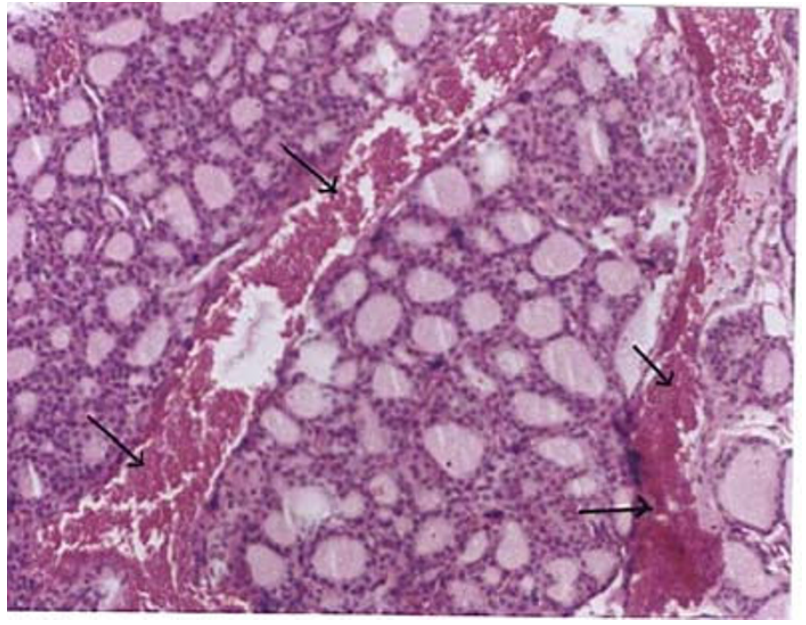

\section{Figure 4}

thyroid tissue of a rat intoxicated with DMN for 2 weeks and treated with green tea for 4 weeks $(H \times \&$ E stain $\times 128$ ).

animals, in agreement with other researchers $[10,11]$ who reported that green tea suppressed the body weight gain as well as the gain of intraperitoneal adipose tissues. However, DMN enhanced that gain. Administration of licorice to DMN-injected animals augmented DMN effect by enhancing that gain, while the mixture or green tea markedly attenuated that effect. This change may be related to the hypertriglyceridemic effect of green tea, which caused the release of lipids from their depots, liver and adipose tissues, and its lowering effect on weight of various adipose tissue $[11,12]$. Administration of tested extracts and

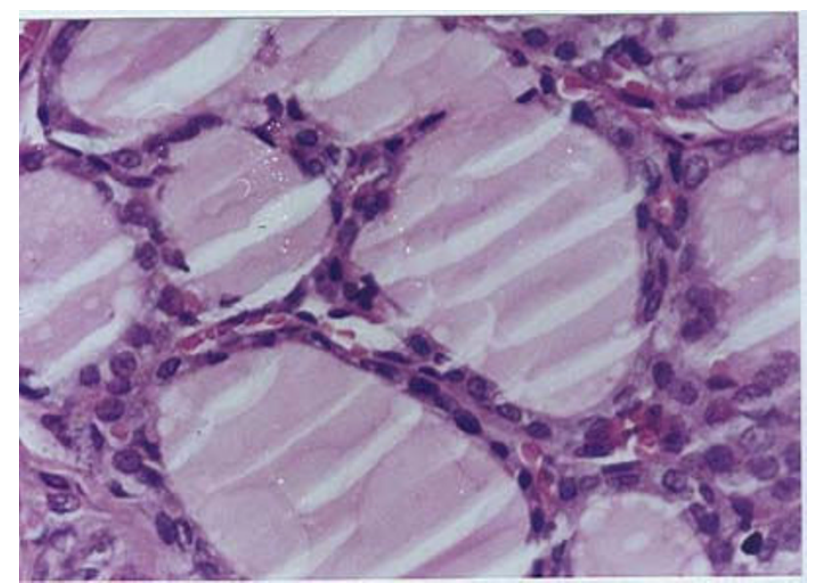

Figure 5

Thyroid tissue of a rat intoxicated with $D M N$ and treated with licorice $(H \times \& E$ stain $\times 5 \mid 2)$.
DMN had insignificant increase in liver weight/body weight \% ratio. The increase was more pronounced in DMN-injected rats. Administration of green tea showed no effect on marked increase induced by DMN intoxication on that ratio, while licorice or mixture augmented this effect. So, it can be concluded that DMN might cause mild liver hypertrophy. However, while licorice or the mixture enhanced that effect, green tea exerted no change on it. In view of the present study, DMN caused substantial decreases in plasma levels of $\mathrm{T}_{3}$ and $\mathrm{T}_{4}$ concentrations consistent with a tremendous increase in plasma level of thyroid-stimulating hormone (TSH). DMN also increased the hepatic activity of thyroxine 5'-monodeiodinase (thyroxine 5'-DI). Thus, the stimulatory effect of DMN on 5'DI was not accompanied with an increase of plasma $\mathrm{T}_{3}$ level. Not only the hepatic 5'-DI activity, but also the continuous release from thyroid gland and uptake of the hormone by the tissues can control $\mathrm{T}_{3}$ level in plasma [13]. Based on this assumption, it is worth mentioning that the decreased level of plasma $\mathrm{T}_{3}$ concentration in DMNinjected animals may be attributed to a decreased secretion and/or an increased uptake or extraction of the hormone by the tissues. Moreover, in parallel with the decrease in $\mathrm{T}_{3}$ and $\mathrm{T}_{4}$ levels in DMN intoxicated animals pathological examination of thyroid tissue, showed degeneration, desquamation and atrophy of many acini as indicated in recent study. Green tea decreased $\mathrm{T}_{3}$ level, although that decrease was statistically insignificant, while it increased the plasma levels of TSH and $\mathrm{T}_{4}$. On the other hand, green tea attenuated the lowering effect of DMN on $\mathrm{T}_{3}$ and $\mathrm{T}_{4}$ levels by increasing these levels, the values are still below the normal control ones. In parallel with amelioration of $\mathrm{T}_{3}$ and $\mathrm{T}_{4}$ levels induced by green tea administration in respect to DMN lowering effect histopathological examination revealed that green tea improved the thyroid perturbations produced by DMN intoxication. Green tea profound the DMN rising effect on TSH level by inducing a slight increase in its level. This is logically accepted because green tea antagonized DMN effect and increased $\mathrm{T}_{3}$ and $\mathrm{T}_{4}$ levels. Green tea induced a decrease in hepatic thyroxine-5'-DI activity but it was statistically insignificant. Also, green tea suppressed the rising effect of DMN on 5'-DI activity by decreasing it, so it is suggested that green tea decreased the rate of conversion of $\mathrm{T}_{4}$ into $\mathrm{T}_{3}$ and the increase of $\mathrm{T}_{3}$ and $\mathrm{T}_{4}$ levels may be attributed to increased secretion and the improvement of thyroid tissue architecture. These observations agree with findings reported by Satoh et al[14]., Licorice induced a decrease in $\mathrm{T}_{3}$ level, while it had no significant change on $\mathrm{T}_{4}$ level. On the other hand, licorice induced a substantial increase in TSH level. Licorice profound the elevated effect of DMN on TSH level. It was remarkable that the effect of licorice and DMN on TSH level was additive. The coadministration of DMN and licorice did not affect the lowering effect of $\mathrm{DMN}$ on $\mathrm{T}_{3}$ and $\mathrm{T}_{4}$ levels. Licorice 
induced an increase in thyroxine 5'-DI activity, but it attenuated the rising effect of DMN on that activity. Linking rise of 5'-DI activity induced by licorice with its lowering effect on $\mathrm{T}_{3}$ level, showing an impression that the stimulated hepatic 5'-DI may be stressed to acclimatize the decrease of $\mathrm{T}_{3}$ level, a kind of compensatory mechanism. Consistent with these results, Martinez-deMena et al.,[15] stated that $\mathrm{T}_{3}$ up regulates 5' DI (type II) in brown adipose tissues. It was obvious that the tremendous increase in TSH level exerted by the mixture was a result of synergistic effect between licorice and green tea. The increase in TSH level was concomitant with the decrease of $\mathrm{T}_{3}$ and $\mathrm{T}_{4}$ levels by the mixture. Surprisingly, although the mixture profound the DMN rising effect on TSH level, the increase was not additive. On the other hand, the coadministration of the mixture with DMN did not significantly affect the lowering effect of DMN on $\mathrm{T}_{3}$ and $\mathrm{T}_{4}$ levels. The mixture decreased thyroxine 5'-DI activity and inhibited the rising effect of DMN on that activity.

In conclusion, these results indicated that administration of green tea alone in DMN-injected animals was more pronounced in increase of $\mathrm{T}_{3}$ and $\mathrm{T}_{4}$ levels than concomitant administration of green tea and licorice. Also this study revealed that the treatment of the DMN intoxicated animals with green tea and/or licorice induced marked amelioration of pathological lesions induced in thyroid tissue manifested by increase in the number and size of follicles which become more organized and appeared to have higher amount of colloid.

\section{References}

I. Weisburger JH, Rivenson A, Garr K, Aliaga C: Tea, or tea and Milk, inhibit mammary gland and colon carcinogensis in rats. Cancer Lett 1997, I | 4:323-7.

2. Ody P: The complete Medicinal Herbal. Dorling Kindersley Ltd, London; 1993:65.

3. Luber S: A review of plant used in the treatment of liver disease: Part two. Altern Med Rev 1999, 4(3): 178-189.

4. Yang CS, Chen L, Lee MJ, et al.: Blood and urine levels of tea catechins after ingestion of different amounts of green tea by human volunteers. Cancer Epidemiol Biomarkers Prev 1998, 7:35I-354.

5. Jeong HG, Kim JY: Induction of inducible nitric oxide synthase expression by 18 beta-glycyrrhetinic acid in macrophages. FEBS Lett 2002, 5 13(2-3):208-12

6. Asakura S, Daimon H, Sawada S, Sagami F: A short-term assessment of tumor-promtion activity in the livers of rats treated with two genotoxic methylating agents: dimethylnitrosamine and methylnitrosourea. Toxicol Lett 1998, 98(3): I55-67.

7. Bu-Abbas A, Dobrota M, Copeland E, Clifford MN, Walker R, loannides C: Proliferation of hepatic peroxisomes in rats following the intake of green tea. Toxicol Lett 1999, 109(I-2):69-76.

8. Kahl S, Capuco AV, Bitman J: Serum concentrations of thyroid hormones and extrathyroidal 5'-monodeiodinase activity during lactation in the rat. Proc Soc Exp Biol Med 1987, I 84: | $44-\mid 50$.

9. Drury M: Work load and the general practitioner. Lancet 1967, 2(7520):823-7

10. Yan $Y$, Zhao X, Zhang L, Liu F: Effect of a complex tea on reducing blood lipid in rabbits. Wei Sheng Yan Jiu 200I, 30(I):52-4.

II. Sayama K, Lin S, Zheng G, Oguni I: Effects of green tea on growth, food and lipid metabolismin mice. In Vivo 2000, 14:48|-4.
12. Hasegawa N, Yamda N, Mori M: Powdered green tea has antilipogenic effect on Zucker rats fed a high-fat diet. Phytother Res 2003, I 7(5):477-80.

13. Ahmed OM, Bstawi M: Effect of ascorbic acid and zink sulphate adminsteatuion on cadmium-induced thyroid dysfunction in albino rats. Jegypt Ger Soc Zool 2002, 38A:387-408.

14. Satoh K, Sakamoto Y, Ogata A, Nagai F, Mikuriya H, Numazawa M, Yamada K, Aoki N: Inhibition of aromatase activity by green tea extract catechins and their endocrinological effects of oral adminitration in rats. Food chem Toxicol 2002, 40:925-33.

15. Martinez-deMena R, Hernandez A, Obregon MJ: Triiodothyronine is required for the stimulation of type II 5 ' deiodinase $m$ RNA in rat brown adipocytes. Am Endocrinol Metab 2002, 282(5): EIII 9-27.

Publish with Bio Med Central and every scientist can read your work free of charge

"BioMed Central will be the most significant development for disseminating the results of biomedical research in our lifetime. "

Sir Paul Nurse, Cancer Research UK

Your research papers will be:

- available free of charge to the entire biomedical community

- peer reviewed and published immediately upon acceptance

- cited in PubMed and archived on PubMed Central

- yours - you keep the copyright 